\title{
Farmers' Knowledge of Cassava Streak Virus Disease in Selected Districts of Central Uganda
}

B. Bua

Department of Agriculture, Kyambogo University, Po Box 1, Kyambogo Kampala (U)

\begin{abstract}
Cassava brown streak disease is one of the latest outbreaks of diseases threatening cassava production in Uganda. Although, previously reported in some parts of east African coast, CBSD was not a common problem in Uganda until over a decade ago. Since, its first reported outbreak in mid 2000s, CBSD has continued to spread in many cassava growing districts of Uganda. Cassava brown streak disease manifests as a syndrome characterised by leaf chlorosis, stem and root necrosis. The infected root tubers are unfit for human consumption. Therefore, the study was conducted to assess farmers' knowledge of CBSD in the selected districts in central Uganda. Semi-structure questionnaires were used to gather information from 180 respondents from the districts of Mukono, Masaka and Wakiso on the knowledge and perception of CBSD. The findings revealed that cassava was widely grown in the three districts. However, a number of constraints including pests and diseases were reported to be affecting cassava growing. Of the diseases, CBSD was ranked as the most widespread and devastating. In fact, $75 \%$ of the respondents had good knowledge of CBSD and perceive it as responsible for the declining cassava production in the districts. The most common symptoms associated with CBSD leaf chlorosis, rotting and necrosis of the root tubers. Both the old and newly introduced cassava varieties were susceptible to CBSD. Accordingly, CBSD was thought of as responsible for food insecurity, livelihoods and the loss of cassava biodiversity among others.
\end{abstract}

Keywords-Chlorosis, necrosis, rotting, susceptible, varieties.

\section{INTRODUCTION}

Cassava (Manihot esculentum Crantz) is an important root crop in many countries of the world including Uganda. Traditionally a subsistence crop, cassava has gained prominence as a potential source of income and food security for the poor and marginalised farming communities in many parts of the world including subSaharan Africa (Dixon et al., 2003). According to FAO (2009), world production of cassava was estimated at 184 million tonnes in 2002, rising to 230 million tonnes in 2008. The world leading producer and exporter are
Nigeria and Thailand, respectively. In Uganda, recent production statistics showed a decline in total production by more than $4.5 \%$ from 1999 to 2009 . The major cause of this tragedy are mainly the biophysical factors of which pests and diseases are most the disastrous followed by lack of improved varieties, inadequate support services, weeds and dynamic weather changes (FAO, 1999). According to IITA (2009), the major pests of cassava in sub Saharan Africa are the cassava green mite and the variegated grasshopper while the main diseases are cassava mosaic disease (CMD), cassava bacterial blight, cassava anthracnose disease and root rot. Cassava mosaic disease (CMD) alone accounted for an estimated $47 \%$ of east and central Africa's cassava production losses during a serious outbreak beginning in the early 1990's until 2006. However, in Uganda the major hindrances to cassava production included insect pests like whiteflies, cassava mealy bugs and the elegant grasshoppers among others. The disease of marked significance is cassava mosaic (CMD) and cassava brown streak disease (CBSD) (Alicai et al., 2007).

Cassava brown streak disease was first reported and distinguished from the cassava mosaic disease (CMD) in Tanzania during the 1930's (Storey, 1936). Cassava brown streak disease (CBSD) was found to be endemic in all east African coastal cassava growing areas from Kenya to Ruvuma River that marks the southern borders between Tanzania and Mozambique. The disease also occurred at lower altitude in Malawi (Nicholas, 1950). However, recent surveys have confirmed that the disease occurs throughout the coastal strip surrounding Lake Malawi (Shaba et al., 2003), coastal Kenya (Bonk, 1994; Muga and Thresh, 2002), and Mozambique (Hillocks et al., 2002; Thresh and Hillocks, 2003). Indeed, the disease is very devastating as it renders the edible roots unsuitable for human consumption (Hillocks and Jennings, 2003). Higher incidences of CBSB in these districts are reported to be closely associated with high whiteflies population (Anon, 2005).

Cassava brown streak disease manifests in a variety of ways, on leaves, it causes yellowing/chlorosis of the leaf margins coalescing into yellow patches whereas on the young stems, the disease appears as brown lesions along the nodes resulting into death of the buds and the 
branches die downwards and on roots, CBSD causes rotting of the edible roots. Estimates of the yield losses attributed to CBSD is scanty and limited because the extent of loss is governed by many factors e.g, susceptibility of the cultivars and stage of harvest. In general, CBSD is insidious, causing mild or no leaf distortion making it hard to notice because the plant looks healthy but the tubers of the plant become yellow/ brown with a corky necrosis making it unfit for consumption by man or animal (Hillocks and Jennings, 2003). However, the symptoms have been noted to be less distinct from other infections and disorders like senescence and those that are as a result of diverse environmental conditions such as prolonged drought that may result in leaf chlorosis (ITTA, 2009). According to Hillocks et al. (2003), the CBSD leaf symptoms are the most distinct indicators of the disease compared to brown streaks on stems as the name suggests and root necrosis which may not occur in some varieties. Therefore, this study was conducted to assess farmers' knowledge and diversity of CBSD symptoms in the selected districts of central Uganda.

\section{METHODOLOGY}

The study was conducted in three selected districts of central Uganda including Mukono, Wakiso and Masaka in 2013. The three districts were chosen because of the outcry about the devastating and widespread reports of cassava brown streak disease (CBSD) as well as the long history of cassava growing in the areas. Multi-stage random sampling technique was used to identify the sub countries, parishes, villages and the respondents to be interviewed. Two to three leading cassava growing sub counties identified from each district were Nama, Seeta Namuganga and Kyampisi (Mukono); Busabala, Kakiri and Busukuma (Wakiso); Kyanamukaka and Kabonera (Masaka), respectively. From each sub county, two major cassava growing parishes were selected depending on the size and intensity of cassava production. In general, 2-3 villages were surveyed per parish depending on the population in the area giving a total of 20 farmers per sub county and 60 farmers per district including one technical staff per sub county. Semi- structured questionnaires were used to gather information from 180 respondents in the three districts. For each of the farmer interviewed, the cassava field was visited to assess the incidence and severity of cassava brown streak diseases using visual symptoms. Disease incidence was assessed as the number of plants diseased expressed as the percentage of the total number of plants assessed per field.

Disease severity was visually assessed as the percent leaf area affected (PLAA) using a scale of $1-5$ where $1=$ no symptoms, $2=$ slight symptoms, $3=$ foliar mosaic, mild stem lesions, no die back, 4=foliar mosaic, severe stem lesions, no die back and $5=$ defoliation, severe stem lesions and die back or $1=$ no apparent necrosis, $2=$ less than $5 \%$ root necrosis, $3=5-10 \%$ root necrosis, $4=10-25 \%$ root necrosis and 5= more than $25 \%$ root necrosis and severe root constriction for root symptoms (IITA, 1995). Diseased cassava plant samples were also collected for laboratory identification of cassava brown streak virus species associated with CBSD and viral characterization. All the data collected was edited, coded and entered into an excel spreadsheet (version 2007). The data was analyzed using descriptive statistics of the SPSS computer package (version 14.0).

\section{RESULTS}

Close to $100 \%$ of the respondents was involved in cassava growing (Table 1). However, the acreages grown vary from 0.25 to 2 acres and above. In fact, close to $90 \%$ grew less than one acre whereas only, slightly above $10 \%$ grew between one acre and above (Table 2). Among the food crops encountered during the survey, cassava was one of the crops reportedly grown for a variety of purpose including consumption, sale and brewing. However, in terms of cash crops, cassava and other crops feature less compared to coffee and banana (Table 3). Overall, cassava has been grown in these districts for over 25 years and above although slightly over $60 \%$ have been growing cassava for between 5 and 10 years (Table 4). The major planting seasons of cassava is presented in Table 5. Slightly over $60 \%$ of the respondents planted cassava in both seasons whereas about $20 \%$ was not sure of the planting seasons. The cassava planting materials used by the respondents were obtained from various sources including own fields, neighbours, NGOs and Government. The varieties grown also varied and ranged from the old and newly introduced varieties (Table 6). Interestingly, the older varieties seem to be more popular than the newly introduced varieties for a number of reasons including inability to access the improved varieties, taste and preferences among others (data not shown). However, a multitude of constraints affecting cassava production were highlighted as shown in Table 7. The most important constraints reported were diseases, drought and pests. In fact, $75 \%$ of the respondents were knowledgeable about cassava brown streak virus disease (Table 8). Cassava brown streak disease was reportedly widespread and devastating in these areas. Cassava brown streak disease was associated with different symptoms as shown in Table 9. The most obvious symptoms of cassava brown streak disease reported were leaf chlorosis and rotting and necrosis of the tubers. However, $50 \%$ of the respondents were not able to tell the causes of cassava brown streak disease although 28.9 and 
$20.9 \%$ associate cassava brown streak to soil and insect related causes (Table 10). Close to $50 \%$ of the respondents attribute the effects of cassava brown streak disease to low yield (Table 10). However, 95\% of the respondents indicated that they don't report the outbreak of cassava brown streak disease to the relevant authority for appropriate action as evidenced by no action reported by $98 \%$ of the respondents (Table 11). Moreso, only negligible percentage of the respondents reported, they were trained on cassava brown streak disease recognition, means of spread and control. Similarly, negligible proportions of the respondents reported that they get information on cassava brown streak disease from the relevant authorities (data not shown). Nevertheless, various attempts for controlling and managing the disease were reported by the respondents. The most commonly reported method of control was roguing as opposed to the use of resistant varieties (Table 12).

\section{DISCUSSION}

The study was conducted to assess the farmers' knowledge and diversity of CBSD symptoms in the selected districts of central Uganda. In fact, the study has shown that $75 \%$ of the respondents were familiar with the disease but, the majority does not report the outbreak to any authority. Similarly, the study has also shown that cassava brown streak disease is a syndrome characterised by leaf chlorosis, streak on the stem and root necrosis. In fact, tubers of the affected plant become yellow/ brown with corky necrosis occurring in the starch bearing tissues, making it unfit for consumption by man or animal (Hillocks and Jennings, 2003). Cassava brown streak disease was also reported to be widespread and devastating in most of the areas visited. This is not strange because like the other diseases farmers always find it difficult to recognize diseases unlike pests they can easily see. Moreover, even those who reported had nothing done to save their crop. Cassava brown streak disease (CBSD) was first reported and distinguished from cassava mosaic disease (CMD) in Tanzania in the 1930's but was confirmed in Uganda by 2000s in highland regions spreading to low land regions like lake Victoria basin (Alicai et al.,2007; Shores, 2011). However, the symptoms have been noted to be less distinct from other infections and disorders like senescence and those that are as a result of diverse environmental conditions e.g. prolonged drought that may result in leaf chlorosis (ITTA, 2009). According to Hillocks et al. (2003), the CBSD leaf symptoms are the most distinct indicators of the disease compared to the brown streaks on stems as the name suggests and root necrosis which may not occur in some varieties. In fact, leaf symptoms present an important tool in reporting the prevalence of the incidence amongst a diversity of cassava varieties in many places. In fact, the outbreak of cassava brown streak disease is a serious threat to food security, livelihoods and loss of cassava biodiversity. This is because whilst considerable efforts have been devoted to come up with varieties resistant to cassava mosaic disease (CMD), these are the same varieties succumbing to CBSD.

\section{ACKNOWLEDGEMENTS}

Funding for this study was provided by Kyambogo University for which I am very grateful. The research assistants who collected the data during the survey are also acknowledged. The cooperation of the farmers during data collection is gratefully acknowledged.

\section{REFERENCES}

[1] Alicai, T. Omongo, C.A,. Maruthis, M.I.V, Hillock, R.C.T. Baguma Y.Kawuki R Otim-G W and Colvin J. (2007). Re-emergence of cassava brown streak disease Uganda. Plant Disease Vol.91:24-29.

[2] Bock, K.R. (1994). Studies on cassava brown streak disease in Kenya. Tropical Science 34, 134-145.

[3] Food and Agriculture Organisation Statistics (FAOSTAT), 2009, production statistics for cassava. Accessed on internet $25^{\text {th }}-01-2912$

[4] Gondwe, F.M.T., Mahungu, N.M, Hillocks, R.J, Raya M.D, Moyo, C.C, Soko, M.M, Chipungu, F and Benesi, I.R.M (2003). Economic losses experienced by small-scale farmers in Malawi due to cassava brown streak virus disease.

[5] Hillocks, R.J, Raya, M.D and Thresh, J.M. (1996). The association between root necrosis and above ground symptoms of brown streak virus infection of cassava in southern Tanzania. Internationa Journal of Pest Management 42:285-289.

[6] Hillocks, R.J and Jennings, D.L (2003). Cassava brown streak disease; a review of present knowledge and research needs. International Journal of Pest Management 49,225-234

[7] Hillocks, R.J, Raya, M.G. and Thresh, J.M.2002. Distribution and symptoms expression of cassava brown streak disease in Southern Tanzania. African Journal of Tuber crops 3:57-67

[8] Hillocks, R.J. Raya, M.G., Mtunda, K. and Kioza, H. (2008). Effects of brown streak virus disease on yield and quality of cassava in Tanzania, Journal of photopathology

[9] Mohammmed, I.U., Abarshi, M.M., Muli, B., Hillocks, R.J. and. Genetic Diversity of cassava Brown Streak Virus infecting cassava in East Africa, Hindawi Publishing Corporation, volume 2012, Article ID 795697, 10 pages 
[10] Jennings, D.L. (1960). Observation on virus disease of cassava in resistant and susceptible varieties II. Brown streak disease. Empire Journal of experimental Agriculture 28:261-269.

[11] Mbanzibwa, D.R., Tian Y.P.Tugume, A.K., Mukasa, S.B Tairo, F., Kyamanya, S., Kalluya, A., Valkonen, J.P.T (2009). Genetically distinct strains of cassava brown streak virus in the Lake Victoria basin and the Indian Ocean coastal areas of East Africa. Achieves of Virology, Vol. 154:353-359.

[12] Monger, W.A, Seal, S, Isaac, A.M and Foster, G. (2007). Molecular characterization of the cassava brown streak virus coat protein. Plant pathology vol. 50: 527-534.

[13] Nicholas, R.F, (1950). The brown streak disease of cassava, distribution climate effects and diagonistic symptoms, East African Agricultural Journal 5:154160

[14] Storey, H.H. (1936). Virus disease of East African plants; VI.A progress report on studies of the disease of cassava. East African Agricultural Journal 2:3439.

[15] Storey, H.H. (1939). Report for 1939 of the cost Agricultural research station, P.9 Teri Shors, (2011). Understanding virus Jones and Bolott publisher copyright-

[16] Uganda National Bureau of Statistic (UBOS). (2009). Production statistics for agricultural products accessed on internet $25^{\text {th }}-01-2012$

Table.1: involvement in cassava growing in Mukono, Wakiso and Masaka districts, 2013

\begin{tabular}{|l|l|}
\hline Cassava growing & Frequency (\%) \\
\hline Yes & 99.4 \\
\hline No & 0.6 \\
\hline Total & $\mathbf{1 0 0}$ \\
\hline
\end{tabular}

Table.2: Acreages of cassava cultivation in Mukono, Wakiso districts, 2013

\begin{tabular}{|l|l|}
\hline Acreages & Frequency $(\%)$ \\
\hline 0.25 & 31.1 \\
\hline 0.5 & 35.0 \\
\hline 0.75 & 22.8 \\
\hline 1.0 & 05.0 \\
\hline 1.5 & 03.9 \\
\hline 2.0 & 01.1 \\
\hline $2+$ & 01.1 \\
\hline
\end{tabular}

Table.3: Food and cash crops grown in Mukono, Wakiso and Masaka districts, 2013

\begin{tabular}{|ll|}
\hline Crops & Frequency (\%) \\
\hline Food & \\
Maize & 2.8 \\
Banana & 18.9 \\
Beans & 1.7 \\
Groundnuts & 0.6 \\
Root crops & 59.4 \\
All & 16.6 \\
\hline Cash & \\
Coffee & 38.9 \\
Banana & 19.4 \\
Beans, & 17.2 \\
groundnuts & 07.2 \\
Banana and coffee & 06.7 \\
Passion fruit & 05.6 \\
Vegetables & 05.0 \\
Root crops & \\
\hline Total & $\mathbf{1 0 0}$ \\
\hline
\end{tabular}

Table.4: Years of involvement in cassava cultivation in Mukono, Wakiso and Masaka districts, 2013

\begin{tabular}{|ll|}
\hline Seasons & Frequency $(\boldsymbol{\%})$ \\
\hline Less 5 & 28.3 \\
$5-10$ & 34.4 \\
$10-15$ & 02.2 \\
$15-20$ & 12.2 \\
$20-25$ & 05.1 \\
$25+$ & 17.8 \\
\hline Total & $\mathbf{1 0 0}$ \\
\hline
\end{tabular}

Table.5: Planting seasons of cassava in Mukono, Wakiso and Masaka districts, 2013

\begin{tabular}{|ll|}
\hline Seasons & Frequency $\mathbf{( \% )}$ \\
\hline Rainy seasons & 09.9 \\
Dry seasons & 10.6 \\
All seasons & 62.8 \\
Not sure & 17.2 \\
\hline Total & $\mathbf{1 0 0}$ \\
\hline
\end{tabular}

Table.6: Source of cassava planting materials and varieties grown in Mukono, Wakiso and Masaka districts, 2013

\begin{tabular}{|ll|}
\hline Source & Frequency $(\boldsymbol{\%})$ \\
\hline Own field & 61.7 \\
Neighbors & 28.3 \\
NGO & 09.4 \\
Government & 0.6 \\
\hline
\end{tabular}




\begin{tabular}{|ll|}
\hline Varieties/cultivars & \\
Bukalasa & 35 \\
TME & 24 \\
Improved & 15 \\
Others & 26 \\
\hline Total & $\mathbf{1 0 0}$ \\
\hline
\end{tabular}

Table.7: Constraints to cassava growing in Mukono, Wakiso and Masaka districts, 2013

\begin{tabular}{|ll|}
\hline Constraints & Frequency (\%) \\
\hline Diseases & 78 \\
Drought & 71 \\
Pests & 67 \\
Shortage of land & 55 \\
Low price & 47 \\
Lack of transport & 38 \\
Soil infertility & 45 \\
Lack of planting materials & 17 \\
\hline
\end{tabular}

Table.8: Knowledge of cassava brown streak disease in Mukono, Wakiso and Masaka districts, 2013

\begin{tabular}{|ll|}
\hline Knowledge & Frequency $(\%)$ \\
\hline Yes & 75 \\
No & 25 \\
Total & $\mathbf{1 0 0}$ \\
\hline
\end{tabular}

Table.11: Reporting and action on the presence of cassava brown streak disease in Mukono, Wakiso and Masaka districts, 2013

\begin{tabular}{|ll|}
\hline Characteristics & Frequency (\%) \\
\hline Report & \\
Yes & 02.8 \\
No & 97.2 \\
\hline Action & \\
No action & 98.3 \\
Action & 01.7 \\
\hline Total & $\mathbf{1 0 0}$ \\
\hline
\end{tabular}

Table.12: Control of cassava brown streak disease in Mukono, Wakiso and Masaka districts, 2013

\begin{tabular}{|ll|}
\hline Method & Frequency \\
\hline Roguing & 52 \\
Spraying & 03 \\
Roguing and spraying & 09 \\
Use of resistant varieties & 01 \\
Do nothing & 35 \\
Total & $\mathbf{1 0 0}$ \\
\hline
\end{tabular}

Table.9: Symptoms of cassava brown steak disease in Mukono, Wakiso and Masaka districts, 2013

\begin{tabular}{|ll|}
\hline Symptoms & Frequency (\%) \\
\hline Leaf chlorosis & 42.2 \\
HL & 15.6 \\
Rotting and necrosis & 39.1 \\
Leaf chlorosis and root & 03.1 \\
necrosis & \\
\hline Total & $\mathbf{1 0 0}$ \\
\hline
\end{tabular}

Table.10: Causes and effects of cassava brown streak disease in Mukono, Wakiso and Masaka districts, 2013

\begin{tabular}{|ll|}
\hline Characteristics & Frequency (\%) \\
\hline Causes & \\
Soil & 28.9 \\
Insects & 20.9 \\
Do not know & 50.2 \\
& \\
\hline Effects & \\
Low yield & 48 \\
Low plant population & 27 \\
Do not know & 25 \\
\hline Total & $\mathbf{1 0 0}$ \\
\hline
\end{tabular}

